\title{
Plaučių embolijos klinikinès išraiškos ir rizikos veiksnių sąsajų tyrimas
}

\author{
PULMONARY EMBOLISM CLINICAL EXPRESSION AND RISK FACTORS INTERFACE \\ INVESTIGATION
}

VYKINTAS ČELKYS, SKAIDRIUS MILIAUSKAS

LSMU MA Pulmonologijos klinika

Department of Pulmonology, Medical Academy, Lithuanian University of Health Sciences

\begin{abstract}
Santrauka. Pacientu tyrimo dèl plaučių embolijos (PE) atranka prasideda nuo šios ligos įtarimo. I ši tyrima buvo ịtraukti asmenys, kuriu klinikinis pasireiškimas svyravo nuo besimptomiu būkliu iki üminių, gyvybei grèsmingu klinikiniu išraiškų, susirge staiga ir tie, kuriems simptomai progresavo lètai. Buvo vertinami žinomi rizikos veiksniai, ju pasireiškimo dažnis ir sąsajos su klinikine išraiška, ieškoma nauju PE išsivystyma galinčiu predisponuoti rizikos veiksnių. Plati pacientu atranka sudare salygas vertinti PE pasireiškimo variantus priartinant juos prie kasdienes praktikos.

Reikšminiai žodžiai: plaučiu embolija (PE), klinikine išraiška, rizikos veiksniai.

Summary. Selection of patients for diagnostic tests for acute pulmonary embolism begins with suspicion of the disease determined by clinical expression, risk factors, understanding of the pathogenesis. Patients enrolled for this study had a broad spectrum of clinical expression - from asymptomic to severe cases, life threating conditions, severe and mild progression disease course. It was appreciated all known risk factors, theirs frequencies, interface with clinical expression, was looking for new, pulmonary embolism predisposal risk factors. Broad patients selection allowed proper pulmonary embolism evaluation approximate to daily practice.
\end{abstract}

Key words: Pulmonary embolism, clinical expression, risk factors.

\section{IVADAS}

Plaučių embolija - viena dažniausių sergamumo ir mirtingumo priežasčiu, nuo kurios Europoje kasmet miršta apie 300000 žmonių: apie 3/4 gydymo ịstaigose, apie 1/4 - visuomenèje [1]. Autopsijos duomenimis, ūmine PE yra sunkiai diagnozuojama liga $[2,3]$. Geresnès diagnostikos galimybès turètų pagerinti šios ligos atpažinimą ir ankstyvą diagnostiką $[4,5]$, kita vertus, sèkmingas diagnostinių algoritmų naudojimas prasideda nuo ligos patogenezès ir klinikinių išraiškų supratimo. Šio tyrimo tikslas - ištirti plaučių embolijos klinikinès išraiškos ir rizikos veiksnių sąsajas.

\section{METODAI}

Išanalizuoti 88 pacientų, gydytų LSMUL Kauno klinikų Pulmonologijos ir imunologijos skyriuje dèl nedidelès rizikos plaučių embolijos nuo $2015 \mathrm{~m}$. spalio 1 dienos iki $2016 \mathrm{~m}$. balandžio 1 dienos duomenys. Duomenys surinkti ūminès PE stacionarinio gydymo metu. Vertintos sąsajos tarp PE klinikinès išraiškos ir rizikos veiksnių. Sąsajos vertintos taikant neparametrinị chi kvadrato $\left(\chi^{2}\right)$ kriterijų pagal Mantelio-Haenzelio (Linear-by-Linear) formulę, kiekybiniai parametrai vertinti taikant Pirsono (Pearson) koreliacijos koeficientą.

\section{REZULTATAI}

I tyrimą įtraukti 40 vyrų ir 48 moterys, kurių amžiaus vidurkis - 67,45 $\pm 14,71$ metų. Sergantieji PE dažniausiai kreipèsi į skubiosios pagalbos skyriu ( 83,72 proc.), rečiau it šeimos gydytoją (16,28 proc.). I šeimos gydytoją dažniau kreipessi besiskundžiantys sausu kosuliu $(\mathrm{p}=0,036)$, o ̣̇ skubiosios pagalbos skyrių - besiskundžiantys ūminiu dusuliu $(\mathrm{p}=0,05)$. Daugiausia pacientų i̇ gydymo isstaigą kreipèsi praejus daugiau nei septynioms paroms nuo simptomų pradžios (37,65 proc.). Per pirmają parą $-35,22$ proc. pacientu, kurie buvo vyresnio amžiaus ( $P e-$ arson koreliacija, $\mathrm{p}=0,05)$, dažniau kreipèsi i skubiosios pagalbos skyriu $(\mathrm{p}=0,027)$, skundèsi ūminiu dusuliu $(\mathrm{p}=0,002)$, lètai progresuojančiu dusuliu $(\mathrm{p}=0,000)$, ūminiu pleurinio tipo skausmu $(\mathrm{p}=0,05)$, sirgo arterine hipertenzija $(\mathrm{p}=0,000)$. Vertinant klinikinius požymius, dažniausiai nustatytas $\mathrm{SpO}_{2}$ sumažèjimas (<94 proc.) 75 proc., tachikardija (>100 k./min.) - 48,53 proc., tachipnejja ( $>24 \mathrm{k} . / \mathrm{min}.)-47,06$ proc. tiriamujų. Pakartotinis PE epizodas nustatytas 14,77 proc. atvejų. Rūkymas (>1 pakmetis) susijęs su pakartotiniu PE epizodu ( $\mathrm{p}=0,007)$. Dažniausi PE būdingi elektrokardiografiniai (EKG) požymiai: ST segmento arba $\mathrm{T}$ dantelio pokyčiai bent dviejose derivacijose (61,54 proc.), $\mathrm{S}_{1} \mathrm{Q}_{3} \mathrm{~T}_{3}$ požymis (56,41 proc.), neigiamas $T V_{1}-V_{3}$ derivacijose $(51,85$ 


\section{Moksliniai darbai}

proc.). Ūminiai dešinès širdies perkrovos echokardiografiniai pokyčiai statistiškai reikšmingai dažniau nustatyti tiriamiesiems, kuriems kartu buvo ir bent vienas EKG požymis, būdingas $\mathrm{PE}(\mathrm{p}=0,036)$.

\section{IŠVADOS}

1. Daugiausia ligonių, sirgusių PE, i skubiosios pagalbos skyrių kreipèsi dèl ūminio dusulio, $i$ šeimos gydytoją - dèl sauso kosulio.

2. Per pirmąją parą nuo simptomų pradžios ị skubiosios pagalbos skyrių dažniau kreipiasi vyresnio amžiaus žmonès dèl ūminių simptomų, sergantys ir arterine hipertenzija.

3. Rūkaliai turi didesnę PE pasikartojimo riziką.

4. Esant nors vienam ūminiam dešiniosios širdies perkrovos EKG požymiui, kartu yra ir bent vienas dešinès širdies perkrovos echokardiografinis požymis.

\section{DISKUSIJA}

Plaučių embolijos diagnozès vyresnio amžiaus žmonèms nustatymas yra gana sudètingas, nes klinikinè išraiška dažniau būna netipinè arba simptomai priskiriami gretutinėms ligoms, arba ignoruojami; vertinami kaip susiję su vyresniu paciento amžiumi. Vis dèlto mūsų tyrimo metu registruotas vidutinis amžius PE nustatymo metu yra didesnis nei panašia metodika atliktų daugelio kitų tyrimų metu $[6,7]$. Atliekant literatūros apžvalgą, nepavyko rasti duomenų apie paciento simptomų ir vietos, $\mathfrak{i}$ kurią kreipési pagalbos, sąsajas, tačiau tikètina, kad turintys mažiau išreikštus ir varginančius simptomus pacientai linkę kreiptis ị šeimos gydytoją nei vykti ị skubiosios pagalbos skyrių, kur vis dèlto vyksta didžioji dalis pacientų ir tai atitinka mokslinių tyrimų duomenis [8]. Autoriai taip pat mano, kad prièmimo skyriuose, ittariant $\mathrm{PE}$, tiriami apie 1,5 proc. visų atvykusių pacientų [6].

Dažniausias pacientų, sergančių PE, skundas yra dusulys, pleurinio tipo krūtinès skausmas, tačiau mūsų tyrimo metu tiksliškai pacientų nebuvo klausiama apie ortopnèjos simptomus, tai, ap̌̌velgiant literatūros duomenis, yra vienas dažniau pasitaikančių simptomų. Sinkopès ištiko tik nedidelę dalį sirgusiųų ūmine PE. Klinikiniai PE požymiai užfiksuoti mūsų tyrime nebūdingi: dažniausiai nustatytas ịsotinimo deguonimi sumažejimas, kuris, galbūt, susijęs su vyresnio amžiaus daugiau gretutinių ligų turinčių pacientų radiniais sunkesnès klinikinès būklès pacientų hospitalizavimu tretinio lygio gydymo įstaigoje, prastesne rankų pirštų kraujotaka $\mathrm{SpO}_{2}$ matavimo metu arba prièmimo-skubiosios pagalbos skyriaus gydytoju sąmoningai dokumentuojamais prastesniais objektyviais parametrais hospitalizuojant pacientą. Kiti klininiai požymiai: tachipnejja, tachikardija atitinka sisteminių apžvalgų duomenis [9].

Netikètų rezultatų neaptikta, vertinant elektrokardi- ografinius pokyčius, būdingus ūminei PE - pokyčiai didžiąja dalimi atitinka literatūroje pateikiamus pokyčius ir jų dažnį: ST segmento arba T dantelio pokyčiai bent dviejose derivacijose, $S_{1} Q_{3} T_{3}$ požymis, neigiamas $\mathrm{T} \mathrm{V}_{1}-\mathrm{V}_{3}$ derivacijose, kai pokyčiai elektrokardiogramoje susiję su struktūriniais arba hemodinaminiais pokyčiais randamais echoskopijos metu [10].

Skirtingai nuo sisteminėse apžvalgose pateikiamų duomenų rastos sąsajos tarp rūkymo ir pakartotinès PE epizodo, galimai sąlygotos mažos pacientų imties, prastesne nei didžiosiose Vakarų šalyse, lėtinių ligų, sukeltų rūkymo ir susijusių su PE rizika, diagnostika [7]. Kita vertus, žinoma, kad rūkymas veikia protromboziškai ir sukelia endotelio disfunkciją, sąlygodamas didesnę išeminių komplikacijų riziką [11], tai atitiktų mūsų tyrime nustatytas sąsajas.

Vis dažniau PE nustatoma atsitiktinai, tai yra nesukelianti jokių klinikinių simptomų. Tokių pacientų gydymas išlieka diskutuotinas. Ateityje, galbūt, būtų tikslinga tokių pacientų ilgalaikè stebėsena, vertinant baigtis skiriant skirtingą gydymą antikoagulaintais arba visai negydant besimptomès $\mathrm{PE}$.

\section{LITERATŪRA}

1. Arya R. Venous thromboembolim prevention. London: Department of Health; 2009.

2. Rubenstein I, Murray D, Hoffstein V. Fatal pulmonary emboli in hospitalized patients (An autopsy study). Arch Intern Med. 1988; 148(6):1425-6.

3. Stein PD, Henry JW. Prevalence of acute pulmonary embolism among patients in a general hospital and at autopsy. Chest. 1995; 108(4):978-81.

4. Stein PD, Fowler SE, Goodman LR, Gottschalk A, Hales CA, Hull RD, et al.; PIOPED II Investigators. Multidetector computed tomography for acute pulmonary embolism (PIOPED II). N Engl J Med. 2006; 354(22):2317-27.

5. Stein PD, Woodard PK, Weg JG, Wakefield TW, Tapson VF, Sostman HD, et al.; PIOPED II Investigators. Diagnostic pathways in acute pulmonary embolism: recommendations of the PIOPED II investigators. Am J Med. 2006; 119(12):1048-55.

6. Stein PD, Beemath A, Matta F, Weg JG, Yusen RD, Hales CA, et al. Clinical characteristics of patients with acute pulmonary embolism: data from PIOPED II. Am J Med. 2007; 120(10):871-9.

7. Stein PD, Saltzman HA, Weg JG. Clinical characteristics of patients with acute pulmonary embolism. Am J Cardiol. 1991; 68(17):1723-4.

8. Venkatesh AK, Kline JA, Courtney DM, Camargo CA, Plewa MC, Nordenholz KE, et al. Evaluation of pulmonary embolism in the emergency department and consistency with a national quality measure: quantifying the opportunity for improvement. Arch Intern Med. 2012; 172(13):1028-32.

9. Stein PD, Willis PW 3rd, DeMets DL. History and physical examination in acute pulmonary embolism in patients without preexisting cardiac or pulmonary disease. Am J Cardiol. 1981; 47(2):218-23.

10. Stein PD, Terrin ML, Hales CA, Palevsky HI, Saltzman HA, Thompson BT, et al. Clinical, laboratory, roentgenographic, and electrocardiographic findings in patients with acute pulmonary embolism and no pre-existing cardiac or pulmonary disease. Chest. 1991; 100(3):598-603.

11. Vyssoulis GP, Karpano EA, Kyvelou SMG, Adamopoulo DN, Vlachopoulos CB, Cokkinos DV, et al. The effect of smoking on inflammation, prothrombotic state and endothelial dysfunction in patients with essential hypertension. High Blood Press Cardiovasc Prev. 2009; 16(2):47-53. 